\title{
Introduction to The Nature of International Humanitarian Law
}

On 17 January 2017, the United Kingdom (UK) Supreme Court delivered its judgment in the case of Serdar Mohammed v. Ministry of Defence, related to the detention by British armed forces of Afghan citizens in the course of their operations in Afghanistan. Lord Jonathan Sumption, writing for the majority, held that '[i]nternational humanitarian law does not specifically authorise detention in a non-international armed conflict.' Instead, the Court found that the authority to detain was provided by the relevant United Nations (UN) Security Council Resolutions, and that 'international humanitarian law regulates its consequences on the assumption that it is an inevitable feature of state practice'. ${ }^{1}$

The judgment illustrates an ongoing debate on the nature of international humanitarian law (IHL). ${ }^{2}$ The latter is usually described as a 'set of rules which seek, for humanitarian reasons, to limit the effects of armed conflict. It protects persons who are not or no longer participating in the hostilities and restricts the means and methods of warfare. ${ }^{3}$ Additional definitions with a similar restrictive wording can be found in the introduction of many IHL textbooks and manuals. ${ }^{4}$ It seems accepted that the primary purpose of IHL is to place restrictions on the actions of parties to armed conflicts, and to impose obligations on them in order to protect the victims thereof. Nevertheless, IHL is also increasingly used to claim the existence of an authority to resort to certain conducts that would be deemed unlawful during peacetime. This may be because ' $[w]$ hen trying to determine the lawfulness of an action, it is always preferable to be able to find the authority for the act under review rather than

1 United Kingdom (UK), Supreme Court, Al-Waheed v. Ministry of Defence; Serdar Mohammed and others v. Ministry of Defence, Judgment, 17 January 2017 [2017] UKSC 2, para. 44.

2 For the sake of clarity, the term international humanitarian law is generally used throughout this book, even when referring to periods when it had not yet been coined and was not in use.

3 International Committee of the Red Cross (ICRC), 'War and Law section', at http://www.icrc.org/eng/war-and-law/index.jsp (accessed 8 February 2020).

4 See Chapter 5, footnote 27. 
having to exclude all possible prohibitions for the act'. ${ }^{5}$ This book aims to determine whether IHL is an exclusively restrictive regime, ${ }^{6}$ composed of prescriptions and prohibitions, or whether it is both restrictive and permissive, and hence also provides permissions. But saying that IHL authorizes, or permits, certain conducts is in itself a highly ambiguous statement. Does it mean that under IHL, 'all means and methods of warfare in armed conflict are permitted (i.e. are lawful) unless prohibited by IHL'? ${ }^{7}$ Or does it mean that IHL explicitly contains legal entitlements to resort to certain conducts? And is there a difference between these two propositions?

The answer to the question on the nature of IHL as restrictive/permissive may vary depending on whether the armed conflict is international or non-international, and on where States and their agents act. In situations where the State party to the armed conflict acts on its own territory, its domestic laws will play an important role in defining the powers its agents enjoy. But when the State acts outside of its own borders, which occurs in international armed conflicts (IAC) and in extraterritorial non-international armed conflicts (NIAC), its freedom to act will be limited by other States' sovereignty. As a consequence, a possible role for IHL is to allocate competences, so that States can rest their extraterritorial acts on mutually-agreed legal bases.

This is precisely the point of our study: during armed conflict, where do State powers come from? Do they come from the principle of sovereignty or do they come from IHL? Does the answer change based on whether the State acts on its own territory or outside of it? Is IHL the source of authority only for extraterritorial acts?

Those questions are not only relevant for determining the source of State competences during armed conflict, or for assessing the theoretical nature of IHL. They also have a practical impact on the application of the law. The simultaneous applicability of international human rights law (IHRL) triggers the same questions. As IHRL contains rules requiring the existence of a legal basis in order for certain rights and freedoms to be restricted, ${ }^{8}$ including during

5 Ian Henderson, The Contemporary Law of Targeting: Military Objectives, Proportionality and Precautions in Attack under Additional Protocol I (Leiden/Boston: Martinus Nijhoff Publishers, 2009), 40.

6 In the context of this book, the term 'restrictive' is understood as meaning 'composed of restrictions, either prohibitions or obligations'. It is used as a synonym to limitative or constraining.

7 Henderson, The Contemporary Law of Targeting (n 5), 40.

8 See discussion of the notion of legal basis, in Chapter 1 at page 9, as well as Chapter 9 on the right to liberty and Chapter 12 the right to life, at page 213 and page 300 respectively. 
armed conflict, ${ }^{9}$ IHL has increasingly been referred to as the regime containing the required authorizations during armed conflict. The development of IHRL therefore means that an absence of prohibition under IHL is no longer sufficient.

One could think that the distinction made here - not prohibited versus permitted through a legal basis - is a distinction without a difference, in the sense that it leads to the same result: in the end the conduct does not violate IHL. But the distinction is fundamental. Precisely because of the requirement that certain conducts find a legal basis in law, even conducts that do not violate IHL may become unlawful under IHRL if they do not at the same time fulfil the latter's requirements. In order to comply with their IHRL requirements, States are now looking for authorizations within IHL.

Finally, the parallel applicability of jus ad bellum is one additional reason why the question of the nature of IHL as permissive/restrictive is relevant. Under the latter, the threat or use of force in international relations is prohibited by the UN Charter. ${ }^{10}$ Exceptions exist to that prohibition, namely when the resort to force is authorized by a UN Security Council resolution, ${ }^{11}$ or when a State acts under its right to individual or collective self-defence. ${ }^{12}$ Because of these exceptions, and even more importantly because of the separation between jus ad bellum and jus in bello, it is widely accepted that the existence of IHL as a regime regulating the exact situation that jus ad bellum aims to avoid - i.e. armed conflict - does not pose a legal problem. And indeed, IHL instruments have made it clear that the individual rules of IHL cannot 'be construed as legitimizing or authorizing any act of aggression or any other use of force inconsistent with the Charter of the United Nations'. ${ }^{13}$ Nevertheless, one cannot disregard the consequence of concluding to the permissiveness of

9 It is widely accepted today that IHRL continues to apply during armed conflict, and may apply extraterritorially. See e.g. ICJ, Legal Consequences of the Construction of a Wall in the Occupied Palestinian Territory, Advisory Opinion, 9 July 2004, para. 106; ICJ, Armed Activities on the Territory of the Congo (Democratic Republic of the Congo v. Uganda), Judgment, 19 December 2005, para. 216; Human Rights Committee, General Comment No. 31, CCPR/C/21/Rev.1/Add.13, 29 March 2004, para. 10; Daragh Murray (ed.), with Dapo Akande, Charles Garraway, Françoise Hampson, Noam Lubell and Elizabeth Wilmshurst (consultant eds), Practitioners' Guide to Human Rights Law in Armed Conflict (Oxford: Oxford University Press, 2016); Cédric Ryngaert, 'Extraterritorial Obligations under Human Rights Law', in Mark Lattimer and Philippe Sands (eds), The Grey Zone. Civilian Protection Between Human Rights and the Laws of War (Oxford: Oxford Hart Publishing, 2018).

Art. 2(4) UN Charter.

Art. 42 UN Charter.

Art. 51 UN Charter.

Preamble Additional Protocol I. 
IHL, in particular if IHL authorizes the use of force against certain individuals. In such a case, not only would the underlying logic and purpose of IHL appear to be in contradiction with Article 2(4) of the UN Charter, but a dangerous situation would be created where the permissive rules of IHL may be used as a justification to violate UN Charter obligations. As a consequence, the nature of IHL will also have an impact on the relationship between jus ad bellum and jus in bello.

With these considerations in mind, our question should be addressed from a dual perspective. On the one hand, we shall look at IHL as a regime: was IHL conceived as both permissive and restrictive, or as exclusively restrictive? What is the overall purpose of the regime? This first, general perspective requires a macro-analysis. On the other hand, we shall also look at individual rules within IHL: it is possible that some of its individual rules present a different nature from what the general regime was meant to be. For instance, even if IHL were thought of as an exclusively restrictive regime, this would not necessarily exclude the existence of specific rules of a permissive nature. This may be for several reasons: in treaties, drafters may have conceived some rules as derogating from the general restrictive approach; or they may have worded provisions they intended as restrictive in a manner that led to their being interpreted in a permissive way; this may also be due to the parallel development of a customary rule of a permissive nature, or again to the fact that IHL is constantly evolving and that rules that were initially restrictive may have been used as permissions over time. This second perspective requires a micro-analysis, looking at specific rules of IHL. 